\title{
Sexual Knowledge, Sexual Attitudes, and Perceptions and Actualities of Sex Education among Elementary School Parents
}

\author{
Hyewon Shin ${ }^{1}$, Jung Min Lee ${ }^{2}$, Ji Young Min ${ }^{3}$ \\ ${ }^{1}$ Assistant Professor, College of Nursing, Clemson University, South Carolina; ${ }^{2}$ Doctoral Student, School of Nursing, University of North Carolina at Greensboro, \\ North Carolina, USA; ${ }^{3}$ Assistant Professor, College of Nursing, Cheju Halla University, Jeju, Korea
}

Purpose: This study was conducted to understand sexual knowledge, sexual attitudes, and the perceptions and actualities of sex education among parents of elementary school children. Methods: This is a descriptive study with a sample size of 337. SPSS version 21.0 was used for data analysis, including descriptive analyses, the t-test, and Pearson correlation analysis. Results: More than $50 \%$ of the participants responded that primary sex education for young children should be the responsibility of the parents and that education should be stared during the elementary school period. A moderate correlation was found between parents' sexual knowledge and sexual attitudes $(\mathrm{r}=.44)$. Most parents were afraid to provide sex education because of their unfamiliarity with teaching methods and their lack of knowledge. However, 50 of the parents wanted to receive sex-related education. Conclusion: We found that parents would like to learn more about sex education from expert lectures or professional organizations. They were interested in topics including the sexual structure of males/females and sexual physiology. Open communication between parents and their children regarding sex-related issues is important. It is crucial to provide accurate and up-to-date sex education information to parents so that they can effectively teach their children at home.

Key words: Attitude; Knowledge; Schools; Sex education; Parents

\section{Corresponding author Jung Min Lee https://orcid.org/0000-0002-4916-5485}

School of Nursing, University of North Carolina at Greensboro, Greensboro, North Carolina 27402, USA

TEL +1-336-865-1134 FAX +1-336-334-3628

E-MAIL_jlee43@uncg.edu

Received May 7, 2019 Revised Jun 6, 2019 Accepted Jun 20, 2019 (a) This is an Open Access article distributed under the terms of the Creative Commons Attribution NonCommercial License (http://creativecommons.org/licenses/by-nc/4.0/) which permits unrestricted noncommercial use, distribution, and reproduction in any medium, provided the original work is properly cited.

\section{INTRODUCTION}

Recently, the importance of sex education at an early age has been increasingly emphasized in the literature due to the ongoing acceleration of elementary school students' physical and mental growth. A study of sixth graders in elementary school showed that more than $30 \%$ of male and female students already had dating experience and that initial engagement in sexual intercourse was being conducted as early as elementary school; this is a surprising finding, but one with unavoidable implications for our society [1]. In addition, the availability of smartphones in elementary schools was found to have reached $37.2 \%$ for primary grade students and $74.2 \%$ for high school students, providing a medium through which some elementary school students are exposed to indiscriminate sex-related content. According to a comprehensive survey on contact and exposure throughout the youth environment, most teenagers first experienced adult videos in elementary school, and the most popular form of media delivery was mobile phones [2]. In a study by Kim [3], elementary school students were not only able to easily access inappropriate content through smartphones, but they also acted as first-person media creators who produced their own content that contained sensitive and provocative content to gain social popularity. Additionally, media images produced by elementary school students themselves show that they can spread 
misinterpretations about sexual awareness and sexual orientation to peer groups. Therefore, appropriate education is necessary before elementary school students are exposed to material that they may not fully understand. However, the current sex education standards of the Government Ministry of Health Welfare in South Korea are somewhat ineffective because although they do address practical sex education (such as content regarding gender discrimination), they have failed to devise fundamental measures to manage the discrepancy between the material and current sex-related problems [4].

Sex education is essential during childhood to establish proper values and attitudes toward sex, especially because these formative years are a potential turning point in reasonable decision-making and rapid changes in physical development [5]. Schools are required to devote 10 hours per year to sex education and to have materials that are developmentally appropriate. However, this content is limited to addressing physical changes based on secondary sexual characteristics, the prevention of sexual violence, and individual efforts to escape the damage of sexual violence. Also, the educational programming is delivered to groups of students in class, rather than in small groups, which is considered to be less effective than small group education [6]. In order for school-aged children to acquire the appropriate sexual knowledge and to maintain desirable gender role attitudes and values, comprehensive sex education should be provided that also includes respect for others (emphasizing egalitarian attitudes), changes encountered during sexual development, and methods to cope with various sexual problems [6].

According to a survey of sixth-graders regarding perceptions of their experiences with sex education, $99 \%$ of boys and girls had previously received some sex education [1]. The majority of sex education offered by schools was conducted by health teachers $(47.3 \%)$, homeroom teachers $(21.7 \%)$, religious representatives $(19.5 \%)$, parents $(6.8 \%)$, external lecturers $(4.5 \%)$, and it was found that sex education was rarely done at home [1].

Parental teaching at home is one of the most important external environments affecting student's learning activities [7]. As parents often serve as role models and are most aware of their children's specific development [8], sex education has been shown to be very effective when parents and children discuss sex-related issues together [9]. However, parents have frequently reported feeling uncomfortable or embarrassed when talking about sex with their children [9]. Jin's [10] study found that parents reported that providing sex education to their children was difficult due to a lack of knowledge of how to teach and provide guidance on sex-related content; therefore, diverse resources should be provided to improve parents' knowledge. As such, parents' levels of sex-related knowledge and sexuality have very strong influences on the formation of sound sex-related values in children. Therefore, it is a prerequisite for parents to have accurate knowledge and desirable attitudes toward participating in their children's sex education at home [6].

Some studies have found that group education can be effective in improving knowledge related to sex and the sexual attitudes of students, but others have shown that little to no change in the sexual attitudes of upper-grade students was achieved. In group education, there are limitations in the content available, and when students ask questions, answers may not be sufficiently conveyed in consideration of others [11,12]. Most agree that it is important to provide formal sex education in school, but it is also important for parents to provide natural and ongoing sexual guidance. Most previous studies were conducted among upper-age school students, such as fourth-to sixth-graders [1,12], were cognitive program studies only for lower-grade school parents [6,13], or investigated the effectiveness of sex education programs $[6,11,12]$. In addition, most previous studies were conducted before smartphone devices became widely available to elementary school students. Therefore, the purpose of this study was to explore sexual knowledge, sexual attitudes, and the perceptions and actualities of sex education among parents with elementary school children. We also expect that the findings of this study could be used as baseline data to develop effective sex education programs for parents.

\section{METHODS}

\section{Design and Sampling}

This was a correlational descriptive study of parents with elementary school children with the goal of better understanding and characterizing their sexual knowledge, sexual attitudes, and perceptions and actualities of sex education. Data were collected using an online survey via Naver Form (a Korean website) so that willing parents of children in the sixth grade or younger could participate. The number of samples was calculated using $\mathrm{G}^{*}$ Power version 3.1.9 according to Cohen's sampling formula. The minimum number of samples was 328 for the t-test at a significance level of .05 , a power of .95 , and an effect size of .40 . The survey was conducted considering $10 \%$ as the non-response rate. In total, 360 parents responded, from whom 337 responses were analyzed after discarding 23 insufficient responses.

\section{Study Tools}

\section{1) Demographics of participants including perceptions and ac- tualities on sex education}


Participants were asked to provide information on their general characteristics including their relationship with their children, age, occupation, dual-income status, education level, family type, number of children, the birth order of elementary school children, and sexual openness. In addition, their perceptions and actualities of sex education were also requested. To measure these, we modified the questionnaires presented in the studies by Jin [10] and Jang [14], after careful consideration of the characteristics of the participants of this study. Permissions was individually obtained by e-mail from the researchers. A total of 21 questions were used to identify parents' perceptions and actualities related to sex education.

\section{2) Sexual knowledge}

To measure participants' sexual knowledge, a questionnaire was derived by modifying the materials presented by Jin [10], with consideration of the participants of this study. Permission was individually obtained by e-mail from the researchers. A total of 48 questions were selected for use. The response for each question consisted of "yes", "no", and "I don't know", with 1 point scored for each correct answer and 0 for each incorrect answer (including responses of "I don't know"). Higher scores indicated higher sex-related knowledge of the participants. The Cronbach's $\alpha$ was found to be .76 in Jin's [10] study, and it was .87 in this study.

\section{3) Sexual attitudes}

The questionnaires used to measure participants' sexual attitudes were modified from those presented in the study by Park [15], again based on participant considerations. Permission was individually obtained by e-mail from the researchers. A total of 17 questions were selected for use. A 5-point Likert scale was used to assign scores from " $0=$ definitely disagree" to " $4=$ definitely agree". The scores of negative questions were reversed. Higher scores indicated that participants were more open toward sex, and lower scores indicated that participants had conservative attitudes toward sex. The Cronbach's $\alpha$ was found to be .86 in Park's [15] study, and it was. 85 in this study.

\section{4) Content validity index}

The modified questionnaire used in this study was reviewed and approved by a group of experts, including two professors from the child and adolescent department and three nurses who had worked in a pediatric unit at a university hospital for over 5 years. The content validity index (CVI) was .81 using the rating of item relevance to check the content validity. Based on the suggestions provided by the experts, five questions with overlapping or ambiguous meanings were modified. In addition, we also conducted pre-testing on $10 \mathrm{pa}-$ rents (five each of lower- and upper-grade children) prior to this survey, and the comprehension and legibility of the questionnaire were verified for use in this survey.

\section{Data Collection}

Data collection for this study was conducted from June 2018 to July 2018. Naver Form, an Internet-based survey application, was used for data collection. In order to recruit participants, we received approval from two online cafes (e.g., Daum and Naver cafes), each of which have more than 250,000 subscribers. After receiving approval from the managers, we posted a detailed description of the purpose and methods of this study that participants could access directly through the link. Those who wished to participate voluntarily in the online survey could sign up for the survey. Before data collection, a page was displayed explaining the participant's rights, anonymity, confidentiality, and data management, and a note explained that they could stop at any time if they did not want to participate further. The questionnaire required 15 20 minutes to complete. This study was approved by the HUniversity Institutional Review Board (HIRB-2018-013). Participants were given an incentive after completing the survey. After reaching the maximum number of participants, the online survey access link was closed. All the data from Naver Form were stored on the author's laptop using secure servers equipped with firewalls and password protected, and the data were accessible only to the research team.

\section{Data Analysis}

The collected data were analyzed using SPSS for Windows version 21.0 (IBM Crop., Armonk, NY, USA). The general characteristics of the participants, as well as parents' perceptions and actualities regarding sex education, were analyzed by frequency and percentage. Sexual knowledge and attitudes were analyzed by means and standard deviation. Differences in sexual knowledge and attitudes according to the general characteristics of the participants were analyzed using the t-test, with the significance level set to .05. The correlations between the subcategories within sexual knowledge and sexual attitudes were calculated with the Pearson correlation coefficient.

\section{RESULTS}

\section{Demographic Characteristics of the Participants}

The general characteristics of the participants were as follows (Table 1). Of the participants, $76.9 \%$ were mothers and 
Table 1. Demographic Characteristics of the Participants

$(N=337)$

\begin{tabular}{|c|c|c|c|}
\hline Characteristics & Categories & $\mathrm{n}(\%)$ & $\mathrm{M} \pm \mathrm{SD}$ \\
\hline Relationship with child & $\begin{array}{l}\text { Mother } \\
\text { Father }\end{array}$ & $\begin{array}{r}259(76.9) \\
78(23.1)\end{array}$ & \\
\hline Age (year) & $\begin{array}{l}20 \sim 29 \\
30 \sim 39 \\
40 \sim 49 \\
\text { Above } 50\end{array}$ & $\begin{array}{c}6(1.7) \\
193(57.2) \\
136(40.5) \\
2(0.6)\end{array}$ & $38.50 \pm 4.24$ \\
\hline Occupation & $\begin{array}{l}\text { Housewife } \\
\text { Office worker } \\
\text { Professional worker } \\
\text { Government worker } \\
\text { Self-employed } \\
\text { Others }\end{array}$ & $\begin{array}{c}150(44.5) \\
110(32.6) \\
26(7.7) \\
15(4.5) \\
21(6.2) \\
15(4.5)\end{array}$ & \\
\hline Both working for a living & $\begin{array}{l}\text { Yes } \\
\text { No }\end{array}$ & $\begin{array}{l}154(45.7) \\
183(54.3)\end{array}$ & \\
\hline Educational background & $\begin{array}{l}\text { Less than high school } \\
\text { College or university } \\
\text { Above graduate school }\end{array}$ & $\begin{array}{r}40(11.9) \\
276(81.9) \\
21(6.2)\end{array}$ & \\
\hline Family type & $\begin{array}{l}\text { Parents and children } \\
\text { Parents, children, and others from the maternal side of the family } \\
\text { Parents, children, and others from the paternal side of the family } \\
\text { Others }\end{array}$ & $\begin{array}{r}311(92.3) \\
15(4.4) \\
10(3.0) \\
1(0.3)\end{array}$ & \\
\hline Number of children & $\begin{array}{l}\text { One } \\
\text { Two } \\
\text { Three or more }\end{array}$ & $\begin{array}{r}120(35.6) \\
179(53.1) \\
38(11.3)\end{array}$ & $1.76 \pm 0.64$ \\
\hline $\begin{array}{l}\text { Elementary school child's } \\
\text { birth order* }\end{array}$ & $\begin{array}{l}\text { First } \\
\text { Second } \\
\text { Third or higher }\end{array}$ & $\begin{array}{c}299(76.5) \\
86(22.0) \\
6(1.5)\end{array}$ & \\
\hline Sexual openness of the participant & $\begin{array}{l}\text { Very closed } \\
\text { Closed } \\
\text { Neutral } \\
\text { Open } \\
\text { Very open }\end{array}$ & $\begin{array}{c}15(4.5) \\
46(13.6) \\
141(41.8) \\
107(31.8) \\
28(8.3)\end{array}$ & \\
\hline
\end{tabular}

*Multiple choices.

$23.1 \%$ were fathers, and their average age was $38.50 \pm 4.24$ years. Among the participants, the age range of 30 39 years accounted for $57.2 \%$ (more than half of the total), followed by those aged $40 \sim 49$ years old (40.5\%). By occupation, housewives accounted for $44.5 \%$ followed by office workers (32.6 $\%)$, professionals $(7.7 \%)$, self-employed $(6.2 \%)$, and government workers/others (4.5\%). Households comprising two working parents accounted for $45.7 \%$ of the total number of households. Regarding educational background, $11.9 \%$ of participants had graduated from high school or below, $81.9 \%$ of the participants had graduated from college or university, and $6.2 \%$ had graduate degrees or above. By family type, $92.3 \%$ of the participants had a family consisting of children and parents. Additional members from either the maternal or paternal side were reported by $7.5 \%$ of participants, and one declared another family type $(0.3 \%)$. The average number of children per family was $1.75 \pm 0.64$. Participants with two children accounted for $53.1 \%$ of respondents, those with one child accounted for $35.6 \%$, and $11.3 \%$ had three or more children. Regarding the birth order of children who were attending elementary school, $76.5 \%$ were the first child, $22 \%$ were the second child, and $1.5 \%$ were the third or higher child in the family. Among the participants, $41.8 \%$ answered "neutral" about their sexual openness, followed by "open" (31.8\%), "closed" (13.6\%), "very open" (8.3\%), and "very closed" (4.5\%).

\section{Parents' Perceptions and Actualities of Sex Education}

The participants' perceptions and actualities of sex education were as follows (Table 2). Of all participants, 53.7\% responded that the primary contributor to children's sex education should be their parents, followed by sex education experts $(29.4 \%)$, teachers or school nurses $(16.3 \%)$, and others $(0.6 \%)$. More than half of the participants $(56.7 \%)$ responded that parents should play a very important role in establishing sex-related values for the children. When asked to specify the 
Table 2. Parents' Perceptions and Actualities of Sex Education

\begin{tabular}{|c|c|c|c|}
\hline Variables & Categories & $\mathrm{n}(\%)$ & $\mathrm{M} \pm \mathrm{SD}$ \\
\hline $\begin{array}{l}\text { Why do you think should be the } \\
\text { primary contributor for sex } \\
\text { education in children? }\end{array}$ & $\begin{array}{l}\text { Parents } \\
\text { Teachers or school nurses } \\
\text { Sex education experts } \\
\text { Others }\end{array}$ & $\begin{array}{r}181(53.7) \\
55(16.3) \\
99(29.4) \\
2(0.6)\end{array}$ & \\
\hline $\begin{array}{l}\text { How important of a role do you think } \\
\text { parents play in establishing their } \\
\text { children's } \\
\text { perspective (viewpoint) on sex? }\end{array}$ & $\begin{array}{l}\text { Not very important } \\
\text { Not important } \\
\text { Neutral } \\
\text { Important } \\
\text { Very important }\end{array}$ & $\begin{aligned} & 1(0.3) \\
& 4(1.2) \\
& 41(12.1) \\
& 100(29.7) \\
& 191(56.7)\end{aligned}$ & \\
\hline $\begin{array}{l}\text { When do you think is the most } \\
\text { appropriate time for your child to } \\
\text { start learning about } \\
\text { sex-related topics? }\end{array}$ & $\begin{array}{l}\text { Toddlerhood (1 3 years old) } \\
\text { Pre-school age ( } 4 \sim 6 \text { years old) } \\
\text { Lower school age (1st to } 3 \text { rd grade) } \\
\text { Upper school age ( } 4 \text { th to } 5 \text { th grade) } \\
\text { Adolescence (12 } 19 \text { years old) }\end{array}$ & $\begin{aligned} & 15(4.5) \\
& 88(26.1) \\
& 121(35.9) \\
& 93(27.6) \\
& 20(5.9)\end{aligned}$ & \\
\hline $\begin{array}{l}\text { When is the best time for you to teach } \\
\text { your child about sex? }\end{array}$ & $\begin{array}{l}\text { According to age } \\
\text { In connection with daily life } \\
\text { When questions are asked } \\
\text { When you see problematic behavior } \\
\text { Others }\end{array}$ & $\begin{aligned} 213 & (63.2) \\
88 & (26.1) \\
28 & (8.3) \\
7 & (2.1) \\
1 & (0.3)\end{aligned}$ & \\
\hline $\begin{array}{l}\text { Do you have experience providing sex } \\
\text { education to your child? }\end{array}$ & $\begin{array}{l}\text { Yes } \\
\text { No }\end{array}$ & $\begin{array}{l}135(40.1) \\
202(59.9)\end{array}$ & \\
\hline If yes, how many times? $(\mathrm{n}=135)$ & $\begin{array}{l}\text { Two times } \\
\text { More than four times } \\
\text { One time } \\
\text { Three times }\end{array}$ & $\begin{array}{l}41(30.4) \\
41(30.4) \\
40(29.6) \\
13(9.6)\end{array}$ & $2.41 \pm 1.21$ \\
\hline $\begin{array}{l}\text { If yes, what was the content about?* } \\
(n=135)\end{array}$ & $\begin{array}{l}\text { Sexual physiology (e.g., pregnancy and childbirth) } \\
\text { Sexual structure of males and females (e.g., menstruation and ejaculation) } \\
\text { Dating and having relationships } \\
\text { How to deal with sexual harassment } \\
\text { Sexual violence (cyber dating etc.) } \\
\text { Masturbation and physical body structure } \\
\text { How to eliminate sexual impulses } \\
\text { Contraception and induced abortion } \\
\text { Sexual intercourse (e.g., position) } \\
\text { Others } \\
\text { Sexually transmitted disease }\end{array}$ & $\begin{array}{l}81(26.6) \\
64(20.9) \\
45(14.8) \\
40(13.1) \\
25(8.2) \\
19(6.2) \\
14(4.6) \\
6(2.0) \\
4(1.3) \\
4(1.3) \\
3(1.0)\end{array}$ & \\
\hline $\begin{array}{l}\text { Has your child ever asked you about } \\
\text { sex? }\end{array}$ & $\begin{array}{l}\text { Yes } \\
\text { Never }\end{array}$ & $\begin{array}{l}180(53.4) \\
157(46.6)\end{array}$ & \\
\hline If yes, what was the content? $(n=180)$ & $\begin{array}{l}\text { Sexual physiology (e.g., pregnancy and childbirth) } \\
\text { Sexual structure of males and females (e.g., menstruation and ejaculation) } \\
\text { Dating and having relationships } \\
\text { Masturbation and physical body structure } \\
\text { How to deal with sexual harassment } \\
\text { Sexual violence (cyber dating etc.) } \\
\text { Sexual intercourse (e.g., position) } \\
\text { Contraception and induced abortion } \\
\text { How to eliminate sexual impulses } \\
\text { Others } \\
\text { Sexually transmitted disease }\end{array}$ & $\begin{array}{c}108(60.0) \\
29(16.1) \\
18(10.0) \\
8(4.4) \\
4(2.2) \\
3(1.7) \\
3(1.7) \\
2(1.1) \\
2(1.1) \\
2(1.1) \\
1(0.6)\end{array}$ & \\
\hline $\begin{array}{l}\text { If your child asks about sex-related } \\
\text { questions, how would you respond }\end{array}$ & $\begin{array}{l}\text { Tell them that as they get older, they will naturally learn it } \\
\text { Yell at them for asking useless questions } \\
\text { Change the subject } \\
\text { Tell them to ask their mother or father } \\
\text { Tell them to ask their teacher } \\
\text { Tell them to consult a book } \\
\text { Teach about the topic in general terms } \\
\text { Teach about the topic in detail } \\
\text { Others }\end{array}$ & $\begin{aligned} & 28(8.3) \\
& 2(0.6) \\
& 18(5.3) \\
& 24(7.1) \\
& 12(3.6) \\
& 11(3.3) \\
& 114(33.8) \\
& 119(35.3) \\
& 9(2.7)\end{aligned}$ & \\
\hline $\begin{array}{l}\text { If your child asks about sex-related } \\
\text { questions, how would you feel? }\end{array}$ & $\begin{array}{l}\text { Very difficult } \\
\text { Difficult } \\
\text { Neutral } \\
\text { Confident } \\
\text { Very confident }\end{array}$ & $\begin{aligned} 50(14.8) \\
61(18.1) \\
119(35.3) \\
77(22.9) \\
30(8.9)\end{aligned}$ & \\
\hline
\end{tabular}

*Multiple choices. 
Table 2. Parents' Perceptions and Actualities of Sex Education (Continued)

\begin{tabular}{|c|c|c|c|}
\hline Variables & Categories & $\mathrm{n}(\%)$ & $\mathrm{M} \pm \mathrm{SD}$ \\
\hline $\begin{array}{l}\text { What is the biggest reason for the } \\
\text { difficulty in providing sex education? }\end{array}$ & $\begin{array}{l}\text { Because I do not know the content and methods } \\
\text { There are not enough textbooks or materials for sex education } \\
\text { Lack of support and community understanding } \\
\text { Feeling awkward and embarrassed to teach about sex } \\
\text { Because of its adverse effects } \\
\text { Others }\end{array}$ & $\begin{array}{c}142(42.1) \\
47(14.0) \\
23(6.8) \\
76(22.6) \\
48(14.2) \\
1(0.3)\end{array}$ & \\
\hline $\begin{array}{l}\text { Have you had sex education for } \\
\text { elementary children's parents? }\end{array}$ & $\begin{array}{l}\text { Yes } \\
\text { Never }\end{array}$ & $\begin{array}{r}62(18.4) \\
275(81.6)\end{array}$ & \\
\hline If yes, how many times? $(n=62)$ & $\begin{array}{l}\text { One time } \\
\text { Two times } \\
\text { Three times } \\
\text { More than four times }\end{array}$ & $\begin{array}{c}34(54.8) \\
19(30.7) \\
6(9.7) \\
3(4.8)\end{array}$ & $1.65 \pm 0.85$ \\
\hline $\begin{array}{l}\text { How necessary do you consider sex } \\
\text { education for elementary school } \\
\text { parents }\end{array}$ & $\begin{array}{l}\text { Unnecessary } \\
\text { Somewhat unnecessary } \\
\text { Neutral } \\
\text { Somewhat necessary } \\
\text { Very necessary }\end{array}$ & $\begin{aligned} 4 & (1.2) \\
6 & (1.8) \\
42 & (12.5) \\
103 & (30.5) \\
182 & (54.0)\end{aligned}$ & \\
\hline $\begin{array}{l}\text { If you think sex education for } \\
\text { elementary children's parents is } \\
\text { necessary, why? }\end{array}$ & $\begin{array}{l}\text { Did not answered (sex education is unnecessary) } \\
\text { Because sex education is part of general human education } \\
\text { To make them have the right attitudes toward the opposite gender } \\
\text { To guide child's curiosity correctly } \\
\text { To prevent sexual misconduct and its damage } \\
\text { Others }\end{array}$ & $\begin{aligned} & 4(1.2) \\
63 & (18.7) \\
98 & (29.1) \\
115 & (34.1) \\
56 & (16.6) \\
1 & (0.3)\end{aligned}$ & \\
\hline $\begin{array}{l}\text { If you think sex education for } \\
\text { elementary children's parents is } \\
\text { unnecessary, why? }\end{array}$ & $\begin{array}{l}\text { Did not answered (sex education is necessary) } \\
\text { Because they are still too young } \\
\text { Too embarrassed to talk about sex with my child } \\
\text { As they grow up, they will learn naturally } \\
\text { The education can disturb children and cause bad results } \\
\text { I feel the need for sex education, but do not know how } \\
\text { Since the education is offered at schools } \\
\text { Others }\end{array}$ & $\begin{array}{l}149(44.2) \\
39(11.6) \\
22(6.5) \\
13(3.9) \\
29(8.6) \\
56(16.6) \\
14(4.2) \\
15(4.4)\end{array}$ & \\
\hline $\begin{array}{l}\text { What do you want to learn if you think } \\
\text { elementary school parents need sex } \\
\text { education? }\end{array}$ & $\begin{array}{l}\text { Sexual structure of males and females (e.g., menstruation and ejaculation) } \\
\text { Sexual physiology (e.g., pregnancy and childbirth) } \\
\text { Sexual intercourse (e.g., position) } \\
\text { Contraception and induced abortion } \\
\text { How to eliminate sexual impulses } \\
\text { Sexually transmitted disease } \\
\text { Dating and having relationships } \\
\text { Masturbation and physical body structure } \\
\text { How to deal with sexual harassment } \\
\text { Sexual violence (cyber dating etc.) } \\
\text { Others }\end{array}$ & $\begin{array}{l}70(20.8) \\
87(25.8) \\
9(2.7) \\
10(3.0) \\
57(16.9) \\
2(0.6) \\
28(8.3) \\
11(3.2) \\
24(7.1) \\
34(10.1) \\
5(1.5)\end{array}$ & \\
\hline $\begin{array}{l}\text { How would you like to learn if you } \\
\text { think elementary school parents need } \\
\text { sex education? }\end{array}$ & $\begin{array}{l}\text { Special lectures by experts } \\
\text { Education through professional counseling organizations } \\
\text { Visual education through digital devices } \\
\text { A sex education booklet } \\
\text { Others }\end{array}$ & $\begin{array}{c}102(30.3) \\
141(41.8) \\
72(21.4) \\
21(6.2) \\
1(0.3)\end{array}$ & \\
\hline $\begin{array}{l}\text { If you need information about sex } \\
\text { education, what source would you } \\
\text { consult? }\end{array}$ & $\begin{array}{l}\text { Hospitals and health centers } \\
\text { Special lectures and seminars } \\
\text { Internet and smartphones } \\
\text { Books and magazines } \\
\text { Family and friends } \\
\text { Others }\end{array}$ & $\begin{array}{c}49(14.5) \\
165(49.0) \\
93(27.6) \\
27(8.0) \\
2(0.6) \\
1(0.3)\end{array}$ & \\
\hline $\begin{array}{l}\text { Are you willing to attend if you have } \\
\text { the opportunity to receive sex } \\
\text { education in the future? }\end{array}$ & $\begin{array}{l}\text { Will gladly attend } \\
\text { Will try } \\
\text { Will think about the situation at that time. } \\
\text { Will not take it } \\
\text { Others }\end{array}$ & $\begin{aligned} 163 & (48.4) \\
126 & (37.4) \\
41 & (12.1) \\
6 & (1.8) \\
1 & (0.3)\end{aligned}$ & \\
\hline
\end{tabular}

${ }^{*}$ Multiple choices. 
most appropriate time for children to receive initial sex education, the most common response was the lower grades (first through third grade) (35.9\%). Furthermore, when asked to identify when would be most appropriate for them to provide sex education, the most common response $(63.2 \%)$ was "according to age".

Parents who had never provided sex education to their children $(59.9 \%)$ outnumbered those who had provided some sex education $(40.1 \%)$. The average number of sessions provided was $2.41 \pm 1.21$. For those with experience providing sex education to their children, the content was related primarily to "sexual physiology" (e.g., pregnancy and childbirth). This accounted for the highest proportion (26.6\%), followed by $20.9 \%$ for "sexual structure of males and females" (e.g., menstruation and ejaculation), and $14.8 \%$ for "dating and having relationships".

Over half of the elementary school children had asked their parents about sex (53.4\%). When children asked about sex, the content of their questions was similar to the above, with the top-ranked subjects being "sexual physiology"(e.g., pregnancy and childbirth) accounting for $60.0 \%$, followed by the "sexual structure of males and females"(e.g., menstruation and ejaculation) at $16.1 \%$, and "dating and having relationships" at $10.0 \%$. When children asked about sex-related questions, $35.3 \%$ of the parents answered that they would teach the topic in detail, followed by $33.8 \%$ who responded that they would teach the basics about the topic, and $8.3 \%$ would tell the child that they would learn it naturally as they grew.

When a child asked questions related to sex, $35.3 \%$ of the respondents stated that their feelings were "neutral", followed by "confident" (22.9\%), "difficult"(18.1\%), "very difficult" (14.8 $\%)$, and "very confident" $(8.9 \%)$, respectively. Regarding the reasons stated for difficulties when providing sex education, $42.1 \%$ of the participants responded "because I do not know the contents and methods", followed by "feeling awkward and embarrassed to talk about sex" (22.6\%), "because of its adverse effects" (14.2\%), and "there are not enough textbooks or materials for sex education" (14.0\%).

Among those surveyed, $81.6 \%$ said they had never received sex education designed for parents of elementary school children. Even for those who had previously received sex education, the average number of sessions was only $1.65 \pm 0.85$; that is, even for parents with experience, it was most common for them to have received fewer than two sessions (54.8\%). However, more than half of the parents $54 \%$ responded that sex education was "very necessary" for them, and 30.5\% responded that it was "necessary" to provide sex education programs for parents. The most common reason given was that they felt they needed sex education to be able "to guide children's curiosity correctly" (34.1\%), followed by "to make them have the right attitudes toward the opposite gender" (29.1\%), and "because sex education is part of general human education" (18.7\%).

More than $40 \%$ of all participants (44.2\%) responded that sex education for parents was necessary. Of those who answered that sex education was not needed, the reason most often given was that "they feel the need for sex education, but do not know how" which accounted for $16.6 \%$ of the responses, followed by "because the children are still too young" $(11.6 \%)$, and "the education can disturb children and cause bad results" (8.6\%). Among the sex-related content, "sexual physiology" (e. g., pregnancy and childbirth) was the most requested topic that participants wanted to receive education on (25.8\%), followed by "sexual structure of males and females" $(20.8 \%)$, and "how to eliminate sexual impulses" (16.9\%), respectively.

Most of the participants responded that they would prefer to be educated by professional counseling organizations (41.8 $\%$ ) or special expert lecturers $(30.3 \%)$ if parents could be provided sex education. In addition, when participants searched for sex-related information for their children, "special lectures and seminars" accounted for the highest proportion of searches $(49.0 \%)$. Most participants responded that they would "gladly $[\cdots]$ participate" in sex education for parents in the future $(48.4 \%)$.

\section{Levels of Sexual Knowledge and Attitudes among Parents}

The participants' sexual knowledge and attitudes were as follows (Table 3). The average sexual knowledge score was found to be $31.54 \pm 7.17$ out of 48 points. Divided by subcategories, "sexual health including sexually transmitted diseases" $(9.79 \pm 3.15)$ showed the highest score, followed by "sexual behavior" (7.51 \pm 2.05$)$, "structure and function of sexual organs" (7.12 \pm 1.84$)$, and "pregnancy and childbirth" (7.05 \pm 1.90$)$. The participants' scores for sexual attitudes were found to be 52.15 \pm 8.21 out of 68 points. Divided by subcategories, "attitudes

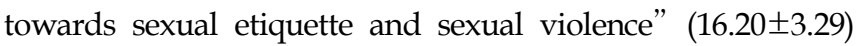
showed the highest score, followed by "attitudes towards sexual perception" (14.92 \pm 2.96$)$, "attitudes toward marriage and childbirth" (12.02 \pm 2.14$)$, and "attitudes toward gender roles" $(9.01 \pm 2.04)$.

\section{Comparison of the Scores of Sexual Knowledge and Sexual Attitudes Based on Demographic Characteris- tics}

Scores for sexual knowledge and sexuality were analyzed in terms of demographic characteristics (Table 4). There were 
Table 3. Levels of Sexual Knowledge and Attitudes among Parents

$(N=337)$

\begin{tabular}{lrrr}
\hline Variables (items) & M \pm SD & Range & Min Max \\
\hline Sexual knowledge (48) & $31.54 \pm 7.17$ & $0 \sim 48$ & $6 \sim 44$ \\
Structure and function of sexual organs (10) & $7.12 \pm 1.84$ & $0 \sim 10$ & $0 \sim 10$ \\
Pregnancy and childbirth (11) & $7.05 \pm 1.90$ & $0 \sim 11$ & $1 \sim 11$ \\
Sexual health including sexually transmitted diseases (15) & $9.79 \pm 3.15$ & $0 \sim 15$ & $0 \sim 15$ \\
Sexual behavior (12) & $7.51 \pm 2.05$ & $0 \sim 12$ & $0 \sim 68$ \\
Sexual attitudes (17) & $52.15 \pm 8.21$ & $0 \sim 20$ & $0 \sim 11$ \\
Attitudes toward sexual perception (5) & $14.92 \pm 2.96$ & $0 \sim 16$ & $4 \sim 20$ \\
Attitudes towards marriage and childbirth (4) & $16.20 \pm 3.14$ & $0 \sim 20$ & $6 \sim 16$ \\
Attitudes towards sexual etiquette and sexual violence (5) & $9.01 \pm 2.04$ & $0 \sim 12$ & $6 \sim 20$ \\
Attitudes toward gender roles (3) & & & $2 \sim 12$ \\
\hline
\end{tabular}

Table 4. Comparison of the Scores of Sexual Knowledge and Sexual Attitudes Based on Demographic Characteristics

$(N=337)$

\begin{tabular}{|c|c|c|c|c|c|c|}
\hline \multirow{2}{*}{ Variables } & \multirow{2}{*}{ Categories } & \multirow{2}{*}{$\mathrm{n}(\%)$} & \multicolumn{2}{|c|}{ Sexual knowledge } & \multicolumn{2}{|c|}{ Sexual attitudes } \\
\hline & & & $\mathrm{M} \pm \mathrm{SD}$ & $\mathrm{t}(p)$ & $\mathrm{M} \pm \mathrm{SD}$ & $\mathrm{t}(p)$ \\
\hline \multirow{2}{*}{$\begin{array}{l}\text { Relationship with } \\
\text { child }\end{array}$} & Mother & $259(76.9)$ & $31.76 \pm 7.05$ & \multirow[t]{2}{*}{$1.05(.296)$} & $52.32 \pm 8.09$ & \multirow[t]{2}{*}{$0.72(.474)$} \\
\hline & Father & $78(23.1)$ & $30.79 \pm 7.57$ & & $51.56 \pm 8.64$ & \\
\hline \multirow{2}{*}{ Age (year) } & $<40$ & $199(59.1)$ & $31.98 \pm 6.76$ & \multirow{2}{*}{$1.34(.182)$} & $51.67 \pm 8.52$ & \multirow[t]{2}{*}{$1.29(.198)$} \\
\hline & $\geq 40$ & $138(40.9)$ & $30.90 \pm 7.70$ & & $52.84 \pm 7.73$ & \\
\hline \multirow[t]{2}{*}{ Employment } & Employed & $172(51.0)$ & $31.40 \pm 7.06$ & \multirow{2}{*}{$0.36(.717)$} & $52.56 \pm 7.68$ & \multirow[t]{2}{*}{$0.93(.352)$} \\
\hline & Unemployed* & $165(49.0)$ & $31.68 \pm 7.31$ & & $51.72 \pm 8.74$ & \\
\hline \multirow{2}{*}{$\begin{array}{l}\text { Both working for } \\
\text { a living }\end{array}$} & Yes & $154(45.7)$ & $31.03 \pm 7.61$ & \multirow{2}{*}{$1.21(.228)$} & $52.46 \pm 7.82$ & \multirow[t]{2}{*}{$0.64(.522)$} \\
\hline & No & $183(54.3)$ & $31.97 \pm 6.78$ & & $51.89 \pm 8.54$ & \\
\hline \multirow[t]{2}{*}{ Education } & Less than high school & 40 (11.9) & $31.03 \pm 5.90$ & \multirow[t]{2}{*}{$0.57(.571)$} & $51.93 \pm 8.41$ & \multirow[t]{2}{*}{$0.18(.855)$} \\
\hline & College or higher & $297(88.1)$ & $31.61 \pm 7.33$ & & $52.18 \pm 8.20$ & \\
\hline \multirow[t]{2}{*}{ Family type } & Parents and children & $311(92.3)$ & $31.63 \pm 7.20$ & \multirow[t]{2}{*}{$0.77(.442)$} & $52.05 \pm 8.19$ & \multirow[t]{2}{*}{$0.80(.425)$} \\
\hline & Others & $26(7.7)$ & $30.50 \pm 6.90$ & & $53.38 \pm 8.51$ & \\
\hline \multirow{2}{*}{$\begin{array}{l}\text { Number of } \\
\text { children }\end{array}$} & One & $120(35.6)$ & $31.82 \pm 7.53$ & \multirow{2}{*}{$0.53(.599)$} & $50.24 \pm 9.09$ & \multirow[t]{2}{*}{$3.21(.001)$} \\
\hline & Two or more & $217(64.4)$ & $31.39 \pm 6.98$ & & $53.20 \pm 7.50$ & \\
\hline \multirow{2}{*}{$\begin{array}{l}\text { Sexual attitudes of } \\
\text { the participant }\end{array}$} & Closed or neutral & $202(59.9)$ & $30.85 \pm 7.46$ & \multirow{2}{*}{$2.24(.026)$} & $51.19 \pm 8.58$ & \multirow[t]{2}{*}{$2.73(.007)$} \\
\hline & Open & $135(40.1)$ & $32.58 \pm 6.62$ & & $53.59 \pm 7.43$ & \\
\hline
\end{tabular}

*House wife \& others.

significant differences in sexual knowledge $(\mathrm{t}=2.24, p=.026)$ and sexual attitudes $(t=2.73, p=.007)$ depending on the sexual attitudes of the participants (closed or neutral/open). Participants who claimed openness regarding sexuality showed statistically significantly higher scores (sexual knowledge: $32.58 \pm 6.62$; sexual attitudes: $53.59 \pm 7.43$ ) than those with neutral or closed attitudes toward sexuality (sexual knowledge: $30.85 \pm 7.46$; sexual attitudes: 51.19 \pm 8.58 ), respectively. There were also significant differences in sexual attitudes depending on the number of children $(t=3.21, p=.001)$. Participants with two or more children (53.20 \pm 7.50$)$ had higher sexual attitudes scores than those with one (50.24 \pm 9.09$)$.

\section{Correlations between Sub-categories of Sexual Knowledge and Sexual Attitudes}

Statistically significant correlations were found between sexual knowledge and sexual attitudes $(\mathrm{r}=.44, p<.001)$, and between the subcategories. Each subcategory between sexual knowledge and sexual attitudes showed correlations ranging from .14 to .46 (Table 5).

\section{DISCUSSION}

This study was conducted to investigate sexual knowledge and sexual attitudes among parents of elementary school students. The average sexual knowledge score was 31.54 , and knowledge about sexual health, including sexually transmitted diseases, was highest among the subcategories of sexual knowledge. The other three subcategory scores had similar average scores. The average sexual attitudes score was 52.15 out of 68 . Of the four subcategories, attitudes toward sexual etiquette and sexual violence had the highest scores. This fact reflects parental concerns regarding sexual violence 
Table 5. Correlations between Sub-categories of Sexual Knowledge and Sexual Attitudes

$(N=337)$

\begin{tabular}{|c|c|c|c|c|c|}
\hline Variables & Total sexual knowledge & & catego & nowlec & \\
\hline Total sexual attitudes & $.44^{* *}$ & SK1 & SK2 & SK3 & SK4 \\
\hline $\begin{array}{l}\text { Sub categories of } \\
\text { sexual attitudes }\end{array}$ & $\begin{array}{l}\text { SA1 } \\
\text { SA2 } \\
\text { SA3 } \\
\text { SA4 }\end{array}$ & $\begin{array}{l}.21^{* *} \\
.25^{* *} \\
.40^{\star *} \\
.23^{\star *}\end{array}$ & $\begin{array}{l}.22^{* *} \\
.14^{* *} \\
.31^{* *} \\
.29^{* *}\end{array}$ & $\begin{array}{l}.16^{* *} \\
.22^{* *} \\
.30^{* *} \\
.22^{* *}\end{array}$ & $\begin{array}{l}.34^{* *} \\
.36^{* *} \\
.46^{* *} \\
.29^{* *}\end{array}$ \\
\hline
\end{tabular}

${ }^{* *} p<.010 ;$ SK1=Structure and function of sexual organs; SK2=Pregnancy and childbirth; SK3=Sexual health including sexually transmitted diseases; SK4=Sexual behavior; SA1=Attitudes toward sexual perception; SA2=Attitudes towards marriage and childbirth; SA3=Attitudes towards sexual etiquette and sexual violence; SA4=Attitudes toward gender roles.

based on the increase in the number of cases of sexual violence against young children.

There were significant differences in sexual knowledge and sexual attitudes depending on the expressed sexual attitudes of the participant (closed or neutral/open). Parents with open sexual perceptions had significantly higher sexual knowledge and sexual attitudes than those with closed or neutral sexual perceptions. In order to provide sex education from home, parents should overcome their fear and bias about sex education and bolster their confidence to openly communicate with their children about sensitive issues [16]. Moreover, several factors have been found to be associated with better communication regarding sex-related issues and the provision of quality guidance, including parents having received sex education from their parents, previous experience providing sex education to their children, the age of parents, higher education levels of parents, higher income levels of parents, and the child's gender [16,17].

Forty-two percent of the parents reported neutral sexual perceptions, and $40 \%$ reported having more open perceptions. This result showed that parents were fairly open regarding sexual attitudes; however, they had generally only received sex education one or two times as a parent. Although their perceptions could be considered open compared to the past, the frequency of the sex education they received was insufficient, indicating an environment similar to the past in that opportunities to receive sex education were minimal.

In this study, $77 \%$ of the participants were mothers. The mothers' sexual knowledge and sexual attitudes scores were higher than those of the fathers, but this trend was not statistically significant. This result is similar to other studies, which found that mothers were more interested in providing sex education for their children and spent more time discussing sex-related issues with them [13]. Further, some intervention studies only included mothers as the providers of sex education for their children $[9,17]$. This trend is similar to studies in the United States where mothers are predominantly cited in most studies as the primary sex educators at home, and mothers are consistently noted as more proactive in engaging their children in talks related to sex. Mothers were also found to be more comfortable discussing sex than fathers [18]. However, mothers were reported to be most comfortable when talking to their daughters about sexuality. The authors therefore addressed the need for fathers to participate in their sons' sex education to discuss male issues more effectively [18]. Parents frequently become role models for their children, and the child's same-gender parent is often best-equipped to affect the child's ability to accomplish his or her goals; therefore, it is important for fathers to provide sex education for their male children [19].

In the current study, no statistically significant difference was found in sexual knowledge based on employment level, education level, relationship with the child (mother or father), or age. This is because the majority of participants in the study were mothers, and most ( $88 \%$ ) reported high education levels (such as college and advanced degrees). In this study, parents with two or more children had higher sexual attitude scores. Those parents might have obtained more experience regarding their children's sex-related education and issues while raising other children. Almost $40 \%$ of parents (35.9\%) reported that lower grade elementary school was the best period to commence initial sex education, and one-third of all participants seemed to believe that most parents welcomed the inclusion of sex education for their children in elementary school. This is similar to other studies' findings $[6,13]$.

Although most parents thought that elementary school was a good time to receive sex education, $60 \%$ of the parents had never provided sex education for their children. The average number of times parents had provided some form of sex education was approximately one or two times. This indicates that most parents had never provided sex education even though the majority thought that sex education should be given to elementary school students and that parents should be the primary contributor to that education. Participants' preferences regarding learning content was evenly distributed, with approximately $20 \%$ for both "sexual physiology" and "sexual structure of males and females". When their children proposed sex-related questions, they most often referred to those two areas. These have always been common topics, as they are important basic information for children [13]. That 
said, sex education content must be updated. These findings are similar to those of studies in the United States, where predominantly normative sex discussions are generally performed along gender and role expectations, and there has been a steady increase in research investigating more sensitive topics including concerns about sexuality [18]. Interestingly, new content continues to be added each year, including dating, relationship building, and dealing with sexual harassment, with the latter becoming a critical topic to prepare children for the steps to be taken to avoid sexual assault or violence. Based on an integrative literature review related to sex education for Korean elementary school students, sexual violence should be considered as an integral part of sex education, but this topic is rarely covered in elementary school textbooks and materials. Students learn about this topic later through middle school textbooks. In order to potentially prevent sexual violence at an earlier age, this content should be included in the elementary school sex education curriculum [20].

Sex education was deemed necessary by parents for two main reasons, "to foster the proper attitudes of children toward each other and both genders" and "to guide children's curiosity correctly". Parents seem like ideal sex educators because they can offer sex education sequentially and provide time-sensitive information as they receive questions from their children [21]. In an Australian study, parents of primary school children answered that sex education was necessary when children are young because they need to know about their bodies and to develop their own sexuality [22]. In particular, girls were considered to need sex education at a young age because their bodies develop more quickly and they could soon become vulnerable to teenage pregnancy and sexual violence [22].

Some parents in the current study did not want to provide sexual education for their children; in particular, $16.6 \%$ felt they did not know how to teach their children and $11.6 \%$ believed that the children were still too young. This result is similar to that of a previous study regarding parents who did not know how to discuss sex-related issues with their children [14]. This finding also aligns with a literature review in the United States, which indicated that several factors affect sexrelated communication between parents and children, including insufficient knowledge about sex, their commitment to become more responsible sex educators for their children, the misinterpretation of discussions regarding sex as permission for the children to have sex, and the perception that their children were not old enough to discuss sex [18]. In two other studies conducted in the United States and Australia, parents thought that their children were too young to discuss sex-related issues regardless of their actual age [22,23]. If children were to learn certain information about sex before reaching sexual maturity, many parents felt that early awareness might provoke risky behaviors due to the immaturity of children's physical and mental development [22].

There was also profound fear from parents about their children's potential "loss of innocence" as a result of sex education [22]. Based on these results, there are conflicting and controversial opinions about the provision of sex education to children in elementary school. Nevertheless, age-appropriate introductory sex education should be conducted by parents with their children to foster the ongoing dialogue required to deal with any concerns and sex-related issues that will soon follow.

Furthermore, $50 \%$ of the parents in the current study wanted to receive sex-related education. This result is similar to the results obtained by Jang [14], who found that more than half of parents wanted to learn more about sex education. It is clear that accurate information regarding sex-education must be available for parents. In our study, we aimed to provide insight into the sexual perceptions, knowledge, and attitudes of parents regarding sex education for their children. Based on this study, we found that parents would like to learn more about sex education and that they maintain open perspectives regarding sex. Many parents would like to provide sex education, but they feel they do not know how to begin. In this study, parents mentioned a preference to receive education from professional organizations or experts. When parents sought sex-related resources, $50 \%$ received information from seminars or lectures, and about one-third searched websites from a smartphone app or an Internet browser. This finding is similar to that of a literature review in the United States [18]. There are reliable resources such as the Centers for Disease Control and Prevention (CDC) and the Sexuality Information and Education Council of the United States (SIECUS) that provide research-based information and proper sex education guidelines according to the children's developmental stage, including the National Sexuality Education Standards [24,25]. However, outside of the classroom, children can often be exposed to unreliable websites. Also, as young children are now technologically proficient, parents must learn how to adjust internet settings to restrict their children's access to risky websites that may expose them to inappropriate sexual behavior [18]. Furthermore, it is sometimes difficult to judge whether a website contains accurate sex education information.

In previous studies, sex education programs were found to be effective in improving parental efficacy, increasing sexual knowledge, and forming positive sexual attitudes $[6,9,14]$. These programs were effective in small groups of parents, but we must find ways to include more parents in classes and develop effective methods to provide education through smartphone apps and Internet-based education for those who cannot attend classes in person. Also, we need to include educa- 
tion for nonparental family members such as aunts, uncles, and grandparents who play adult roles in lieu of parents for children who do not live with their biological parents [18].

Based on the findings of this study, we would like to suggest implications for nursing and public health regarding sex education. Continuous and open communication between parents and their children is essential for discussing any sexrelated issues. It is important to specifically include fathers as a communicators or educators for their sons regarding sex issues. Some parents fear providing sexual education for their children and do not know how to provide proper education for their children. Parents would like to learn through seminars, schools, or experts. Thus, policymakers and schoolteachers need to provide parents resources with up-to-date and accurate information. Furthermore, parents need to know how to set up internet settings to prevent their children from accessing risky websites.

This study had a sufficient sample size, however, it was limited to a descriptive study with the intent of providing data related to the sexual knowledge and sexual attitudes of parents. In order to obtain a deeper understanding of parental perspectives, focus groups and qualitative interviews can be conducted to elicit additional information. It is also worth noting that we used an Internet-based survey that relied on self-reporting. Therefore, the data may not be fully reliable, depending on the sincerity of the respondents' answers. This self-response bias may also occur in paper-pencil surveys. In order to increase the likelihood of analyzing sincere responses and improve reliability, we checked respondents' answers and removed surveys with incomplete responses $(6 \%$ of the total surveys).

\section{CONCLUSION}

This study concluded that many parents maintained open perceptions about sexual attitudes, but had rarely received any formal sex education through schools or experts. They were willing to learn more about sex-related topics to benefit their children. Parents also thought that elementary school is an appropriate time to start the initial phases of sex education. Based on these findings, it is important for parents to learn more about sex education from experts or educators who are better qualified to provide the most accurate and recent information, while training parents to effectively teach sex-related issues to their children at home. The delivery of sex education might include fathers and non-family members, and various methods should be used to effectively convey the material, including methods for those who cannot attend regular in-person sessions.

\section{Conflict of interest}

No existing or potential conflict of interest relevant to this article was reported.

\section{REFERENCES}

1. Park BO. Association with the opposite sex and sex attitudes of 6 th grade elementary students. The Korean Journal of Health Education. 2018;4(1):59-88.

2. Ministry of Gender Equality and Family. Survey on the harmful environment of teenagers. Status Report. Seoul: Ministry of Gender Equality and Family; 2014 December. Report No.: 2014-52.

3. Kim AM. An exploratory study on children's YouTube culture: Focusing on children's communication culture. Korea Children's Media Society Spring Conference; 2018 June 9; Korea National University of Education. Cheongju: The Korea Society for Children's Media; 2018. p. 179-195.

4. Kim AY. Gender equality, not inequality promoting sex education. Naeil news [Internet]. 2015 August 26 [cited 2019 Apr 01]; Social. Available from:

http://www.naeil.com/news_view/?id_art=163498.

5. Kar SK, Choudhury A, Singh AP. Understanding normal development of adolescent sexuality: A bumpy ride. Journal of Human Reproductive Sciences. 2015;8(2):70-74.

https://doi.org/10.4103/0974-1208.158594

6. Lee EM, Kim H. Development and effects of a children's sex education program for the parents of lower elementary grade students. Journal of Korean Academy of Nursing. 2017;47(2):222-232. https://doi.org/10.4040/jkan.2017.47.2.222

7. Khu BY, Lee JA. The structural relationships among perceived parenting roles, teacher leadership, leaning motivation for leaning flow in elementary school students. Korean Journal of Youth Studies. 2015;22(6):355-387.

8. Somers CL, Anagurthi C. Parents' attitudes about adolescents' premarital sexual activity: The role of inter-parent consistency/inconsistency in sexual outcomes. Health Education Journal. 2013;73(5): 545-553. https://doi.org/10.1177/0017896913506702

9. Lee EM, Kweon YR. Effects of a maternal sexuality education program for mothers of preschoolers. Journal of Korean Academy of Nursing. 2013;43(3):370-378.

https://doi.org/10.4040/jkan.2013.43.3.370

10. Jin HS. Sexual knowledge and perception and current status of sex education among parents of first and second grade elementary schoolers [master's thesis]. Seoul: The Catholic University of Korea; 2011. p. 1-42.

11. Im YL, Park KM. Effects of sexuality education coaching program on sex-related knowledge and attitudes among elementary school students. Journal of Korean Academy of Nursing. 2014;44(1):3140. https://doi.org/10.4040/jkan.2014.44.1.31 
12. Kim SJ, Lee JE, Kim SH, Kang KA. The effect of sexual education on sex knowledge and attitudes in elementary school students. Journal of Korean Public Health Nursing. 2012;26(3):389-403. https:// doi.org/10.5932/JKPHN.2012.26.3.389

13. Jin HS, Park HR. Sexual knowledge and perception and current status of sex education among parents of first and second grade elementary schoolers. Journal of Korean Academy of Child Health Nursing. 2011;17(3):198-205.

https://doi.org/10.4094/jkachn.2011.17.3.198

14. Jang HJ. Effects of sex education programs for preschool parents [master's thesis]. Seoul: Hanyang University; 2016. p. 1-74.

15. Park KS. A study on parents education program for domestic sex education of their pre-puberty children [master's thesis]. Uijeingbu: Shinhan University; 2016. p. 1-129.

16. Jerman P, Constantine NA. Demographic and psychological predictors of parent-adolescent communication about sex: A representative statewide analysis. Journal of Youth and Adolescence. 2010;39(10):1164-1174. https://doi.org/10.1007/s10964-010-9546-1

17. Jo MJ, Lim KJ, Choi EJ. Influencing factors of marital intimacy and sexual knowledge on parental efficacy of mothers with preschoolers on child sexual education. Journal of Korean Public Health Nursing. 2018;32(2):181-193.

https://doi.org/10.5932/JKPHN.2018.32.2.181

18. Flores D, Barroso J. 21st century parent-child sex communication in the United States: A process review. The Journal of Sex Research. 2017;54(4-5):532-548. https://doi.org/10.1080/00224499.2016.1267693

19. Kim KM, Doh HS, Park SY. The relationship among parenting be- haviors, children's perfectionism and achievement motivation. Korean Association of Child Studies. 2010;31(2):209-227.

20. Shin H, Lee JM, Kang KA, Kim SJ. An integrative literature review on sexual abuse prevention education program for elementary school students in South Korea. Child Health Nursing Research. Forthcoming 2019 October 31.

21. Krauss BJ, Miller KS. Parents as HIV/AIDS educators. In: Pequegnat W, Bell CC, editors. Family and HIV/AIDS: Cultural and contextual issues in prevention and treatment. New York: Springer; 2012. p. 97-120.

22. Robinson KH, Smith E, Davies C. Responsibilities, tensions and ways forward: Parents' perspectives on children's sexuality education. Sex Education. 2017;17(3):333-347. https://doi.org/10.1080/14681811.2017.1301904

23. Pariera KL. Barriers and prompts to parent-child sexual communication. Journal of Family Communication. 2016;16(3):277-283. https://doi.org/10.1080/15267431.2016.1181068

24. Centers for Disease Control and Prevention (CDC). Parent and guardian resources [Internet]. United States: CDC; 2017 [cited 2017 April 19]. Available from:

https://www.cdc.gov/teenpregnancy/parent-guardian-resources /index.htm.

25. Sexuality Information and Education Council of the United States (SIECUS). National Sexuality Education Standards: Core content and skills, K-12 [Internet]. United States: SIECUS; 2012 [cited 2019 Apr 01]. Available from: https://siecus.org/wp-content/uploads/2018/07/National-Sexual ity-Education-Standards.pdf. 